\title{
意識的目標と非意識的目標はどのように異なるのか？ 教示またはプライミングによるステレオタイプ抑制の効果
}

\author{
及川昌 典*
}

近年の目標研究によって, 意識的な目標追求と非意識的な目標追求は, 同じような特徵や効果を持つ ことが明らかになっている。しかし，これら 2 つ目標追求が，どのような状況で，どのように異なる のかは明らかではない。本研究は, 抑制のパラダイムを用いて, 教示による意識的抑制と, 平等主義関 連語をプライミングすることによる非意識的抑制との相違点を明らかにするために行われた。実験 1 で は，非意識的に行われる抑制においては，意識的に行われる抑制に伴う弊害である抑制の逆説的効果が 生じないことが示された。教示により外国人ステレオタイプの記述を避けた群は, 後続の課題で, かえつ てステレオタイプに即した印象形成を行うのに対し，非意識的に抑制を行った群では，そのような印象 形成は見られなかった。実験 2 では，非意識的な抑制は，意識的な抑制よりも効率的との想定を基に， 相対的に抑制に制御資源が消費されないだろうと予測された。抑制後に行われた自己評定においては, 意識的抑制群においてのみ, 強い疲弊感が報告されていたが, 後続のアナグラム課題においては, 意識 的抑制群も非意識的抑制群も同様に課題遂行が阻害されており, 両群において消費される資源量には違 いがないことが示された。抑制意図と行動，それに伴う意識の関係について論じる。

キーワード : 自動動機, 思考抑制, 逆説的効果, 制御資源, ステレオタイプ

\section{問題と目的}

我々の意図と行動，そして意識との関係は，時に非 常に複雑である。同じ仕事でも，知らぬ間に終わって しまったように感じるほど順調に進む時もあれば，な ぜか思ったようにはかどらない時もある。

近年, 意図的に掲げる目標と共に，当事者の意識な しに行われる目標や目標追求行動に強い関心が寄せら れるようになってきた。我々が意識的に行う目標追求 と, 非意識的に行う目標追求にはどのような相違点が あるのだろうか。

意識的目標と非意識的目標 目標を扱う従来の研究 の中心的関心は, 目標を内容によって分類し, それら の目標が動機づけや行動に及ほす影響を明らかにする ことであった (e.g., 内発的動機づけと外発的動機づけ, Deci \& Ryan, 1985 ; 理想自己と当為自己, Higgins, 1987 ; 遂行目標と学 習目標, Dweck \& Leggett, 1988 ; 長期目標と短期目標, Mischel, Shoda, \& Rodriguez, 1989)。これらの研究では, 人は自分 の持つ目標を認識し，選択することで，その目標の実 現に向かって行動を生起させると暗に想定されていた。 対して, 近年の研究では, 人の目標追求行動の多くが, 実際には, 当事者の自覚なしで行われていることが示

\footnotetext{
一橋大学大学院社会学研究科
}

され，非意識的な目標追求を積極的に扱うようになっ てきた (e.g., Bargh, 1990 ; Bargh \& Gollwitzer, 1994 ; Bargh \& Chartrand, 1999 ; Oikawa, 2004)。例えば, Bargh, Goll witzer, Lee-Chai, Barndollar, \& Trötschel (2001, 実 験 2) の研究では, 2 人の参加者に競争か協力の 2 種類 の戦略を取ることができるゲームを行わせた。ゲーム 前に乱文構成課題によって「協力」と近い意味の語句 を刺激として与えられていた群は, 協力の戦略を取り やすくなり，「競争」関連語を含んだ文章を与えられた 群は, 競争の戦略を取りやすくなった。全ての参加者 は, ゲームの前に行った乱文構成課題によって方略選 択にプライミング効果が生じたことに気づいていな かった。これらの結果は, 語句による目標関連刺激と の接触が, 参加者の戦略決定に非意識的に影響するこ とを示し，すなわち，人は与えられた刺激に反応して 特定の目標(競争か協力)を追求する行動をとることを示 している。このような, 当事者にとって非意識的な目 標追求行動は, 自動的に生じる動機と言う意味で, 一 般に自動動機（auto-motive）と呼ばれている。

このように，我々は，意識的に何か目標を揭げ，そ の追求を目指す場合と, 環境からの刺激によって自動 的に目標追求を行う場合とがあるようだ。では，非意 識的な目標追求は，どのような特徵を持つのだろうか。 Bargh et al.（2001）は，非意識的な目標であっても， 
意識的な目標の典型的な特徵である「達成されるまで は, 時間が経つにつれて動機づけが高まること」「障害 に直面しても一貫した姿勢をとること」「追求が中断さ れても後に再開すること」といった特徵を持つことを 実証的に示している。また, Chartrand\&Bargh(1996) は, 印象形成の目標を持った参加者の方が, 記憶目標 を持った参加者よりも記憶成績が高まったとする Hamilton, Katz, \&Leirer (1980) の研究を非意識的目 標で再現し, 非意識的な目標追求が意識的な目標追求 と変わらないと主張している。このように, 現在の自 動動機研究では, 自動的に生じる目標追求と, 意識的 に生じる目標追求は, 同質であることが強調されてい る。

しかし, 意識的な目標追求と, 非意識的な目標追求 は, 本当に同じ特徵を共有すると考えて良いのだろう か? 目標追求に限らず, 人の意識を伴わずに生じる過 程全般を考えてみると, 意識的過程(しばしば統制過程と も呼ばれる)と非意識的過程(しばしば自動過程とも呼ばれる) によって生じる結果が, 同質であるという想定には, 疑問が残る。

例えば, Bargh (1994) は, 以下のような特徵を挙 げ，自動性を定義している。自動過程は，a）始動時 に意図が必要とされない非意図性，b ）即時的に反応 が生じる即時性，c）実行に必要とされる資源が極め て少ない効率性, d ) 実行に意識が伴わない無自覚性, e ）実行されている過程や影響を制御できない制御困 難性, の特徵のうち，1 つ以上の特徵を有するとされ る (詳細は, 池上, 2001 ; 森・木村, 2004 参照)。対して, 統制 過程とは, 実行に意図や意識が伴い, 自動過程から遅 れて始動し, 機能するのに資源が必要とされ，また制 御することが可能であると考えられる。

自動性を取り入れた近年の研究では, 多くの社会的 判断や行動は，刺激に対して一次的に生じる自動的な 反応を, 統制過程が二次的に変容, 修正した結果とす る想定が主流である (e.g., ヒューリスティックーシステマ ティックモデル, Chen \& Chaiken, 1999 ; Devine の二過程モデ ル, Devine, 1989 ; セットーリセットモデル, Martin, 1986 ; 包含一 除外モデル, Schwarz \& Bless, 1992 ; Trope の段階処理モデル, Chaiken \& Trope, 1999 など)。これらの研究では, 自動過 程によって生じる人の行動や判断は，しばしば短絡的 であったりバイアスがかかったりする “不十分な”反 応であるが，これは，統制過程を経ることにより，“社 会的に適切な” 反応へと変わると考えられている。こ のように，統制過程はいわば意図を持つ人間らしい反 応を作り出す過程であり，社会生活において欠くこと
はできないと考えられている。

しかし，このような統制過程も，万能というわけで はない。先行研究では見過ごされてきたが, 統制過程 には，自動過程にはない制限もある。例えば，意図を 持つことによる弊害が生じることや，機能させるため に相当の資源が必要となることである。よって，統制 過程の限界点を正確に把握することが, 自動過程と統 制過程の特徵を理解するためには重要であると考えら れる（同様の議論は Higgins \& Bargh, 1992; Fiske, 1998; 池上 2001)。

以上の議論を踏まえ, 本研究では, 非意識的目標追 求と意識的目標追求は同じではなく, 異なる特徵もあ ると考え，この両者の比較検討を行う。また，この際 に，これまでの研究では見過ごされがちであった統制 過程のコスト，特に意図を持つことの弊害と必要とな る資源量，にも焦点をあてることとする。

統制過程のコスト 1 一意図を持つことの弊害として の抑制の逆説的効果一 大学進学を目指す, 健康的な 生活を送るなど, 我々は日常的に様々な意識的目標を 掲げているが,これらの実行には, 既述したように, 様々な制限がある。例えば，平等主義的な信念を守る ために，ステレオタイプの使用を回避するという目標 を考えてみると, 不適切な思考, ステレオタイプを制 御するためには，a） 自分がステレオタイプを使用し ているという認識（気ゔき）が必要であり，b）ステレ オタイプを使用しないという動機づけが必要であり, そしてc）ステレオタイプを制御するための制御資源 が必要である (e.g.. Devine, 1989)。さらに，意識的な制 御には, 思わ弊害が伴うことがあることも知られて いる。

意識的制御の反意図的な効果として，抑制の逆説的 効果, すなわち, ある思考を抑制しょうとするほど, かえってその思考が生じやすくなってしまう現象が知 られている (e.g., Wegner. Schneider, Carter, \& White, 1987 ; Clark. Ball, \& Pape. 1991 ; Davies \& Clark, 1998 ; 木村, 2004)。 Macrae, Bodenhausen, Milne, \& Jetten (1994) の研 究では,ステレオタイプを抑制しようとすると,かえつ てそのステレオタイプに準じた判断や行動が高まって いた。現在までの研究で, 抑制の逆説的効果は皮肉に も，当事者の抑制意図が強いほど強まることが示唆さ れている(木村, 2003)。このような，抑制しようと努力 するほど，かえって失敗が促されてしまう現象は，意 識的な制御の弊害と考えられている。

もし，抑制の逆説的効果が積極的な抑制意図を持つ ことで生じているのであれば，意図の伴わない非意識 
的な抑制ならば，この効果は生じないと考えられるだ ろう(同様の議論は, 麦谷, 2004)。本研究では, ステレオ夕 イプ抑制のパラダイムを用いて，この可能性を検討す る。

統制過程のコスト 2 一制御資源の消費一 我々は統 制過程を通じて意思の力を行使し, 自らの行動・思考・ 感情・動機を調整しているが，この制御は無制限に可 能というわけではなく，その実行には制御資源が必要 となる。制御資源とは，自己の制御を行うための資源 であり，ある時点において個人が持つ制御資源には限 りがあると考えられている (e.g., Baumeister, Bratslavsky, Muraven, \& Tice, 1998 ; Muraven \& Baumeister, 2000)。

近年の研究では, この制御資源が枯渴すると, 続い て行われる課題の遂行が阻害されることが明らかと なってきている。例えば，自己制御を必要とする課題 を行った後では, それに続く課題の持続時間が低下し たり (Muraven, Tice, \& Baumeister, 1998; Webster, Richter, \& Kruglanski, 1996), 他者を考慮した適切な社会行動が 取れなくなる (Finkel \& Campbell, 2001)。

近年では，抑制においても，制御資源が大きな役割 を果たすことが明らかになってきた。抑制は一種の自 己制御であるため，これを行うためには，制御資源が 必要となる。Gordijn, Hindriks, Koomen, Dijksterhuis, \& Van Knippenberg（2004）は，抑制を試みると, 他の制御課題と同様に，制御資源を枯渴させること(実 験 1)，また，いったん抑制を行うと，続けて行われる抑 制に顕著な逆説的効果が生じること (実験 4) を示して いる。すなわち，考えまいと意識的に努力すると，自 己の制御が必要となり, 資源が消費されるため, 続け て抑制することが困難になるのだろう。

非意識的な目標追求では意図的にこのような抑制を 努力することはない。そのため, 制御資源の消費は生 じないか，あるいは，低減されるかもしれない。本研 究の第 2 の目的は，抑制における制御資源の消費を検 討することにある。

本研究の目的 以上の議論をまとめると, 本研究の 目的は次のようになる。本研究は, 意識的な目標追求 と非意識的な目標追求の相違点を明らかにするために, ステレオタイプ抑制課題を用いて検討を行う。抑制し ようと意図的に努力する抑制課題では，その意図の弊 害である逆説的効果や(統制過程のコスト1)，自己制御を 発動させるために制御資源の枯渴が生じ（統制過程のコ スト2)，抑制の失敗の原因となっている。よって，「抑 制しよう」と意識する目標追求では，抑制の逆説的効 果が生じるのに対し，それを明確に意識しない非意識
的な目標追求では，このような逆説的効果が生じない かもしれない。実験 1 では，ステレオタイプを抑制し た後の, 抑制の逆説的効果の検討を行う。実験 2 では, 抑制に必要とされる制御資源に焦点をあて，非意識的 な目標と意識的な目標による抑制後の制御資源を比較 検討する。

\section{実 験 1}

実験 1 では，教示により意識的に，もしくはプライ ミングにより非意識的に，ステレオタイプの抑制を動 機づけ，その影響を検討する。Macrae et al. (1994)の 研究では，ステレオタイプ的な記述を抑制させると, 後の印象形成判断でよりステレオタイプ的な印象形成 がされていた。この研究を参考に, 実験 1 では, 外国 人労働者ステレオタイプを用い, まずステレオタイプ 的記述の抑制を行い, 後に他の外国人に対する印象形 成において抑制の逆説的効果が生じるかどうかを検討 する。この際, 意識的抑制群と非意識的抑制群を用意 し，比較検討を行う。

抑制を教示によって行った群（=意識的抑制群）では， 後続課題において，抑制の逆説的効果が生じるだろう。 しかし，抑制をプライミングによって行った群(=非意 識的抑制群) では, 後続課題において, 逆説的効果が生 じないと予測される。

\section{方法}

実験計画 1 要因 3 水準（意識的抑制群,非意識的抑制群, 統制群）の被験者間計画。

参加者 都内の大学生 59名(男性24名, 女性35名; 平均年 路19.41 ( $S D=2.41$, 範囲 $=18-29))$ が参加した。 5 つ以上の 回答項目に欠損のあった 3 名を分析から除外し, 最終 的に56名のデータが分析に用いられた。

手続き 実験は授業時間内を利用した一斉調查形式 で行われた。「他の実験刺激作成のための予備調査」と 称して, 調査を構成する課題は互いに無関連であるこ と, 実験の進行は実験者の指示に従って同時に進める ことが説明された。

参加者には無作為配置された条件に応じて異なる調 査冊子が配布された。実験は 3 つのセクションによっ て構成されていた。まず,「他の実験のための刺激調査」 と称して, 乱文再構成課題 (scrambled sentence task ; Srull \&Wyer, 1979) によるプライミング操作が行われた。プ ライミング操作には， 5 つの単語セットの内 4 つを選 んで文法上適切な文章を構成することを求める課題を 用いた ( $\mathrm{T}_{\mathrm{ABLE}}$ 1)。非意識的抑制条件の単語セットは, 平等目標に関連する文章が完成されるように作成され 
TABLE 1 プライムとして使用した単語セットの例

\begin{tabular}{|c|c|}
\hline 平等関連単語セット & 統制単語セット \\
\hline $\begin{array}{l}\text { 接する, 公平に, やはり, 誰とでも, 彼は } \\
\text { 平等という, 向かって, 理想に, 努力する, いつも } \\
\text { 機会が, 均等な, 与えられた, 全ての人に, 㕍用の } \\
\text { 中立な, 考えて, 立場から, 見直す, もういちど } \\
\text { 神は, 愛した, 同じように, 全ての人を, いつでも }\end{array}$ & $\begin{array}{l}\text { 楽しむ, 休暇を, やはり, いつも, 彼は } \\
\text { 平和という, 向かって, 理想に, 努力する, いつも } \\
\text { 機会が, またとない, 与えられた, ついに, 雇用の } \\
\text { 前回の, 考えて, 展開から, 見直す, もういちど } \\
\text { 母は, つくった, } 3 \text { 週間で, セーターを, いつでも }\end{array}$ \\
\hline
\end{tabular}

た。意識的抑制条件と統制条件の単語セットは，平等 とは無関連な中性的な文章が完成されるように作成さ れた。これまでの研究において, 平等主義が活性化する とステレオタイプ的判断が空えられることが示されて おり (Moskowitz, Gollwitzer, Wasel, \& Schaal, 1999 ; Moskowitz, Salomon, \& Taylor, 2000), 本研究では,これに準 じて平等関連語によるプライミングが採択された。こ の乱文構成課題は10問から成っていたため, 非意識的 抑制条件では，10の平等主義関連の文章を，意識的抑 制群および統制群では，10の中性文章を完成させたこ とになる。また, 課題は, 平等関連語でも中性語でも 完成時には，ほほ同じ文法構成になるように作成され ていた。先行研究では,このような乱文構成課題によっ て課題中に特定の意味概念に接触させると, その影響 や操作の意図を自覚させずに概念の接近可能性を高め ることが確認されている（Bargh \& Chartrand, 2000； Bargh et al., 2001)。参加者は実験者の合図で一斉に課題 を始め, 各自のペースで全ての問題に解答した後に白 紙のページに進み, 実験者の次の合図を待った。回答 に費やされた時間は約 5 分間だった。

次に, Macrae et al. (1994) や Gordijn et al. (2004)

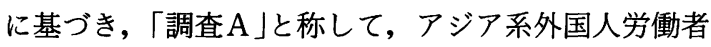
「へイン」の典型的な一日を想像して，5分間ででき るだけ詳細に記述するように求める課題を行った。解 答用紙には, 外国人男性の写真が印刷されており，そ の右横にはへイン，神奈川県在住とだけ記載されてい た。ただし意識的抑制群にのみ，「偏見や固定観念に基 づく記述は，絶対に排除する」ように追加教示が記載 されていた。参加者は実験者の合図で一斉に 5 分間課 題を行った。その後, 疲弊感を測定するため, 記述課 題（調査 A）の感想として，「難しかった」,「疲れた」, 「神経を使った」,「努力を要した」の 4 項目に対して, 7 件法 (全く当てはまらない 1 ～非常によく当てはまる) で回 答を求められた。

続いて，「調査 B」と称して，連続して複数の写真の 人物に対する印象評定を求める課題を行った。解答用 紙には，1ページに 1 枚ずつ, 日本人男性 (フィラー), アジア系外国人男性, 日本人女性 (フィラー) の順に,
顔写真が印刷されており，その下には，評定項目リス トが記載されていた。日本人男女についての評定は フィラーであり, 従属変数となったのは, この内, ア ジア系外国人男性に関する項目, すなわち, 裕福(逆転 項目), 怖い, 信用できる (逆転項目), 怠惰の 4 項目であっ た。この 4 項目は, 「外国人労働者に対するステレオタ イプ的特徴」を自由記述させた予備調査 ${ }^{1} に$ 基づき, 頻 度の高い順に選択された。これに実験の目的を曖昧に するためのフィラー項目 2 項目（愉快な, 稻やかな）が加 えられていた。この課題における外国人労働者ステレ オタイプに合致した 4 項目の評定得点を平均して，ス テレオタイプ化得点とした(クロンバックの $\alpha=.82) 。$

最後に, プライミング操作の影響や目的，また，セ クション間の関連性を自覚していなかったことを確認 するために, 質問紙への回答を求めた。具体的には, Bargh \& Chartrand (2000) を参考に, 課題間に関連や 相互への影響があったと思うかを尋ねた。「ある」と答 えた参加者については，その内容について詳細な回答 を求めた。課題の関連性について，仮説に関連する影 響を回答した者はいなかった。 結果

ステレオタイプ的記述 実験仮説および概要を知ら

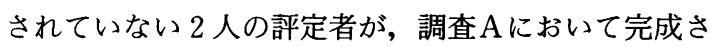
れた記述内容の全体的なステレオタイプ度を，6件法

(全くステレオタイプ的ではない 1 6 非常にステレオタイプ的 である)で評定した。この評定には，ステレオタイプ化 得点で用いられた 4 つの形容詞の強さが基準とされた。 すなわち, 評定者は, “裕福”, “怖い”, “信用でき る”, “急惰”に関連する記述がどの程度含まれている かを基準に記述全体のステレオタイプ度を評定した (TABLE 2)。この際, 評定者間一致率が低かったため(評 定者間一致率 $=.69)$, 評定の不一致は, まず, 事後的な話

外国人労働者ステレオタイプの内容を知るために, 38名の大 学生に外国人労働者に関するステレオタイプ的特徵をできる だけ速く 5 つ列挙させた。この内容を 2 名の評定者が分類し, 刺激語として選択した。結果は, 多い順に,「語学に関する記述」 「犯罪に関する記述」「経済状態に関する記述」「宗教に関する 記述」「勤勉性に関する記述」であった。 
TABLE 2 条件ごとの記述のステレオタイプ度，リバウンド，資源消費量（実験 1)

\begin{tabular}{cccc}
\hline 実験条件 & 意識的抑制 & 非意識的抑制 & 統制 \\
\hline$N$ & 19 & 18 & 19 \\
ステレオタイプ度 & $2.79(1.69)$ & $3.06(1.73)$ & $5.11(1.66)$ \\
印象形成(リバウンド) & $4.58(0.90)$ & $3.42(1.20)$ & $3.92(1.40)$ \\
資源消費量(自己報告) & $5.37(1.26)$ & $4.00(1.71)$ & $4.05(1.61)$ \\
\hline
\end{tabular}

*括弧内は標準偏差。資源消費は，高い值ほどより疲労度が高いことを示す。

し合いによって解消され，最終的な評定結果の妥当性 が第 3 の評定者によって判断された。調査 $\mathrm{A}$ の記述内 容におけるステレオタイプ度の差異を検討するために, ステレオタイプ度の評定得点に対して，一元配置の分 散分析を行った。実験条件の主効果 $(F(2,53)=10.58$, $p<.001)$ が有意であり, 多重比較 (HSD) の結果, 意識 的抑制群と非意識的抑制群は, 統制群に比べて, 記述 内容のステレオタイプ度が有意に低いことが認められ た(意識的抑制群 $M S e=.55, p<.001$; 非意識的抑制群 $M S e=.56$, $p<.001)$ 。意識的抑制群と非意識的抑制群の結果には有 意な差は見られなかった $(M S e=.56, n s$.$) 。すなわち, 教$ 示によって明示的に抑制を導出した場合も，プライミ ングによって暗示的に抑制を導出した場合も, 統制群 に比べて，ステレオタイプ的な記述が抑制されるとい う予測は支持された。

印象形成課題(逆説的奻果) 抑制の弊害として知られ る逆説的効果の生起を検討するために, 調査 B $\mathrm{B} お け$ る外国人労働者ステレオタイプに合致した 4 項目の評 定得点を平均して ( $\left.\mathrm{T}_{\mathrm{ABLE}} 2\right)$, ステレオタイプ化得点と した(クロンバックの $\alpha=82)$ 。この得点に対して, 一元配 置の分散分析を行った。実験条件の主効果 $(F(2,53)=$ $4.47, p<.05)$ が有意であり, 多重比較 (HSD) の結果, 意識的抑制群は, 非意識的抑制群や統制群に比べて, ステレオタイプ得点が有意に高かった (非意識的抑制群 $M S e=.39, p<.01$; 統制群 $M S e=.40, p<.05)$ 。非意識的抑制 群と統制群の結果には有意な差は無かった $(M S e=.39$, $n s$.$) すなわち, 意識的な抑制後には抑制の逆説的効果$ が生じるが, 非意識的な抑制後には, 逆説的効果は生 じないという予測は支持された2。

制御資源消費量（自己評定）調査 $\mathrm{A}$ における疲弊に ついての 4 項目の平均得点を算出し ( $\left.\mathrm{T}_{\mathrm{ABLE}} 2\right)$, 制御資 源消費得点とした(クロンバックの $\alpha=.83)$ 。この制御資源 消費得点に対して，一元配置の分散分析を行った。実 験条件の主効果 $(F(2,53)=4.78, p<.05)$ が有意であり, 多重比較 (HSD) の結果, 意識的抑制群は, 非意識的抑 制群や統制群に比べて, 制御資源消費得点が有意に高 いことが示された（非意識的抑制群 $M S e=.51, p<.05 ;$ 統制 群 $M S e=.50, p<.05)$ 。非意識的抑制群と統制群の結果に
は有意な差はなかった $(M S e=.51, n s$.$) 。すなわち, 意図$ 的な抑制後は制御資源が消費され，疲弊感が高まるが， 非意識的な抑制においては，そのような効果が生じな い可能性が示唆された。

考察

実験 1 では, 教示もしくは平等主義関連の単語のプ ライミングによってステレオタイプ使用の抑制を行い, 印象形成課題を通じて, 抑制の逆説的効果の生起につ いて検討した。

まず，目標が教示による意識的なものでも，プライ ミングによって非意識的に活性化したものであっても, 外国人労働者に関するステレオタイプ的な記述は統制 群よりも有意に少なく，また両群では差がなかった。 すなわち，プライミングによる操作であっても，抑制 が自発的に生じたと解釈でき, 意識的目標同様, 非意 識的目標が追求されるという今までの自動動機研究の 主張 (e.g, Bargh, et al., 2001 ; Chartrand \& Bargh, 1996) を 裏付ける結果であったと言えよう。

しかしながら, 意識的抑制群と非意識的抑制群は, 後続の印象形成課題において, 異なる結果を示してい た。抑制を教示によって行った意識的抑制群では, 統 制群に比べ，よりステレオタイプ的な評定を行う，抑 制の逆説的効果を生じさせていたのに対して, 非意識 的抑制群では, 印象評定值が統制群と変わらず, 逆説 的効果は見られなかった。これは，抑制の逆説的効果 は，教示による外発的な抑制で生じるが，内発的・自 発的な抑制では生じ難いとする Föster \& Liberman (2001) や麦谷 (2004) の主張とも整合する。本研究の結 果は，この自発的な抑制がプライミング操作によって

意識的抑制群での主観的疲弊感が, その条件での印象評定の 低さに直接影響したのではないかという別解釈を排除するた めに, 試みに, フィラー項目での分析も行った。具体的には, 日本人男性刺激に対する，「空腹な」「男らしい」「眠そうな」「明 るい」の項目，日本人女性に対する「疲れている」「音楽好き」 「丁寧な」「話下手な項目である。全ての項目で, 群間で有意 な差は見られなかった。よって, 群間の違いは, 単なる疲弊か ら来るものではなく, 外国人労働者の刺激に特化して生じてい たことが示された。すなわち, 抑制を試みた群においてのみ, 抑制の逆説的効果が生じていたと解釈できるだろう。 
生じたと解釈できる。

更に，抑制に関する制御資源の消費を反映している と考えられる, 疲弊度の評定においても, 意識的, 非 意識的目標に違いが見られた。意識的抑制群でのみ, 統制群よりも高い疲弊感が報告されており，抑制に必 要とされる制御資源の消費が大きかったと考えられた。 すなわち，意識的目標は，抑制しようとする意図を持 つ故に，制御資源がより必要となり (Gordijn et al., 2004 実験 1), その後の課題の抑制が失敗したのかもしれな い(Gordijn et al., 2004, 実験 4)。

実験 1 の結果をまとめると, プライミングにより非 意識的に抑制を行った非意識抑制群は, 教示により意 識的に抑制を行った意識的抑制群と同様に，ステレオ タイプ的記述を避けていた。しかし，意識的抑制群が, 後続の印象形成課題において高いステレオタイプ的評 定を行ったのに対し，非意識的抑制群は行わなかった ことから，明示的な抑制意図がない抑制は逆説的効果 を生じさせないと考えられた。この理由の一つとして, 意識的目標の遂行は制御資源を消費させるのに対し, 自動的に行われる非意識的目標の遂行は, 効率性が高 く, 制御資源を必要としないことが考えられる。

しかし, 実験 1 で制御資源を測定した指標は, 疲弊 感の自己報告であり，制御資源の枯渴を厳密に反映し ていたかは疑問が残る。実験 1 の結果は, この指標に

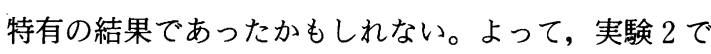
は，抑制の制御資源の枯渴量を測定するために頻繁に 用いられているアナグラム課題を用いて (e.g., Muraven et al., 1998 ; Baumeister et al., 1998)，意識的，非意識的抑 制の遂行において, 消費される制御量に違いが生じる かを検討する。Baumeister らの一連の研究によると， 自己制御を要する課題を行うと, 個人の持つ有限の制 御資源が消費され，自我枯渴状態 (ego-depletion) とな り, 制御資源が回復するまで, 後続の自己制御課題の 遂行が阻害されるという (e.g.. Baumeister et al., 1998 ; Muraven et al., 1998 ; Baumeister, Muraven, \& Tice, 2000)。 もし，非意識的に行われる抑制が，意識的に行われる 抑制よりも，効率的ならば，抑制に制御資源が消費さ れず,よって, 後続のアナグラム課題に影響が見られ ないだろう。

\section{実 験 2}

実験 2 では，ステレオタイプ的な記述の抑制を行っ た後, 印象形成課題に替わり,アナグラム課題を提示 することで，制御資源の測定を行う。Muraven et al. (1998) は, 制御資源を注意などの認知処理資源とは異
なるものとして論じている。具体的には，注意などの 認知処理資源説では, 二重課題など並列的に行われる 課題において, その一時点での資源が低下し, 遂行が 阻害されることを扱うのに対し, 制御資源説では, 続 けて行われる課題での遂行の阻害を扱う。制御資源は, 制御資源を要する課題が終わっても, 回復するまで時 間がかかり，その間は自己制御を用いる他の課題への 影響が見られるという。この影響の測定には，アナグ ラム課題の遂行量がしばしば使用されてきた（e.g. Baumeister et al., 1998)。

実験 2 は，以下の予測に基づいて行われた。意識的 に抑制を行う群では, 制御資源が枯渴し, 後続のアナ グラム課題の成績が阻害されるだろう。一方, 非意識 的に抑制を行う群では, 意識的抑制群よりも制御資源 の消費が少なく, 後続の課題に影響が見られないだろ う。

\section{方法}

参加者 都内の大学生, 専門学校生60名(男性36名, 女 性24名：平均年齢 $(S D=19.88$, 範囲 $=18-22))$ が実験に参加し た。

実験計画 1 要因 3 水準 (意識的抑制群, 非意識的抑制群, 統制群) の被験者間計画。

手続き 実験 1 に準じた手続きが用いられた。実験 は,「他実験の刺激作成のための予備調査」と称して, 授業時間内を利用した一斉調査形式で行われた。

3 条件に無作為配置された参加者は, まず，プライ ミング操作である乱文再構成課題を行い, 次に, 「調查 $\mathrm{A} 」$ と称して, 実験 1 と同様に, 外国人労働者「へイ ン」の典型的な一日を想像して，5分間で記述する課 題を行った。その後, 疲弊感を測定する項目に回答し た。

続いて，「調査B」と称して,アナグラム課題を行っ た。この課題では, 例えば,「サ・イ・キ・ン・ケ」の ように，5文字のカタカナを並べ替えて単語を作るこ とが求められた(「ケイサンキ」)。アナグラム課題は記憶 の単純な検索だけではなく, 制御的な認知操作を必要 とするため制御資源の乏しい状態では課題成績が低下 することが確認されている (e.g., Baumeister et al., 1998)。本研究では， 5 分間の制限時間内に，24問のア ナグラム課題にできるだけ回答するように求めた。

最後に, 実験 1 と同様, プライミング操作の影響や 目的，また，セクション間の関連性の自覚に関する質 問を行った。課題の関連性や先行課題の影響について, 仮説に関連する影響を回答した者はいなかった。 
結果

ステレオタイプ的記述 実験 1 と同様に, 実験仮説 や概要を知らされていない 3 人の評定者が, 調査 $\mathrm{A} の$ 記述内容の全体的なステレオタイプ度を，6件法で評 定した(評定者間一致率 $=.82$ )。すなわち, 評定者は, “裕 福”，“怖い”，“信用できる”, “怠惰”に関連する記述 がどの程度含まれているかを基準に記述全体のステレ オタイプ度を評定した。この結果を TABLE 3 に示す。 また, 評定の不一致は, 事後的な話し合いによって解 消された。また， 1 次評定に 1 以上の差が認められる ことはなかった。調査Aの記述内容におけるステレオ タイプ度の差異を検討するために, ステレオタイプ度 の評定得点に対して, 一元配置の分散分析を行った。 実験条件の主効果 $(F(2,57)=7.51, p<.001)$ が有意であ $\eta$, 多重比較 (HSD) の結果, 意識的抑制群や非意識的 抑制群は, 統制群に比べて, 記述内容のステレオタイ プ度が有意に低かった（意識的抑制群 $M S e=.56, p<.01$; 非 意識的抑制群 $M S e=.56, p<.01)$ 。意識的抑制群と非意識的 抑制群の結果には差はなかった $(M S e=.56, n s$.$) 。これは$ 実験 1 を再現する結果であり, 教示によって明示的に 抑制を導出した場合も，プライミングによって抑制を 導出した場合も, 統制群に比べて, ステレオタイプ的 な記述が少なかった。

制御資源消費量（自己評定）調查Aにおける疲弊に ついての 4 項目の平均得点を算出し ( $\left.\mathrm{T}_{\mathrm{ABLE}} 3\right)$, 制御資 源得点とした(クロンバックの $\alpha=.86)$ 。制御資源得点に対 して, 一元配置の分散分析を行った。実験条件の主効 果 $(F(2,57)=7.31, p<.001)$ が有意であり, 多重比較 (HSD)の結果, 意識的抑制群は, 統制群に比べて, 制 御資源消費得点が有意に高く報告され $(M S e=.39, p<$ $.001)$, 非意識的抑制群と他の 2 つの群の結果には差が 見られなかった（意識的抑制群 $M S e=.39, n s$; ; 統制群 $M S e=$ .39, ns.)。これにより, 意識的抑制群のみが, 統制群に 比べて課題の困難感や疲弊を高く感じていたことが示 された。

制御資源消費量（アナグラム課百）抑制後の制御資源
の枯渴について検討するために, 調査 B のアナグラム 課題の遂行数 ( $\mathrm{T}_{\mathrm{ABLE}} 3$ ) に対して, 一元配置の分散分析 を行った。実験条件の主効果 $(F(2,57)=18.72, p=.001)$ が有意であり, 多重比較 (HSD) の結果, 意識的抑制群 や非意識抑制群は, 統制群に比べて, アナグラム課題 遂行数が有意に低かった（意識的抑制群 $M S e=1.40, p<$ .001 ; 非意識的抑制群 $M S e=1.40, p<.001)$ 。しかし, 予測に 反し, 意識的抑制群と非意識的抑制群の結果には有意 差はなかった $(M S e=1.40, n s$.$) 。すなわち, 意識的抑制群$ においても, 非意識的抑制群においても, 制御資源は 同程度に消費されたことが示された。

\section{考察}

実験 2 では, 抑制によって消費される制御資源に焦 点をあて, 意識的目標と非意識的目標による抑制の影 響を検討した。

実験 1 同様, 抑制が教示による意識的なものでも, プライミングによる非意識的なものでも, 外国人労働 者に関連するステレオタイプ的な記述は統制群よりも 少なく,よって, 抑制が生じていたことが示唆された。 また, 自己報告される課題遂行の疲弊度は, 意識的抑 制群のみ, 統制群よりも高く報告され, 教示による抑 制が, 非意識的に生じる抑制よりも, 実行に困難を感 じさせることが示唆された。この結果は, 実験 1 を再 現するものであり, 意識的な抑制は制御資源の消費が 著しいため，抑制が困難になる可能性が考えられた。

ところが, 予測に反して, 抑制後の残存する制御資 源量を実際に測定したアナグラム課題においては, 意 識的抑制, 非意識的抑制の両群で課題遂行数には差が なく, 統制群よりも少なかった。すなわち, 主観的に は, 疲弊感を報告しなかった非意識的抑制群も, 抑制 によって制御資源が消費されており, 後続の課題にお いて課題遂行が阻害されていた。つまり, 制御資源が 不足している自我枯渴状態となっていたことが示唆さ れた。

TABLE 3 条件ごとの記述のステレオタイプ度, 資源消費量, 後続課題の成績（実験 2)

\begin{tabular}{cccc}
\hline 実験条件 & 意識的抑制 & 非意識的抑制 & 統制 \\
\hline$N$ & 20 & 20 & 20 \\
ステレオタイプ度 & $2.45(1.73)$ & $2.40(1.73)$ & $4.30(1.84)$ \\
資源消費量(自己報告) & $5.18(1.25)$ & $4.49(1.38)$ & $3.68(1.08)$ \\
制御資源(課題成績) & $10.45(3.52)$ & $11.45(5.42)$ & $18.30(4.09)$ \\
\hline
\end{tabular}

*括弧内は標準偏差。資源消費は, 高い值ほどより消費していたことを示す。 制御資源 (課題成績)は，低い值ほど，制御資源が少ないことを示す(範囲： 0-24)。 


\section{総合考察}

非意識的目標を扱う従来の研究は, 意識的目標と非 意識的目標の類似点を示し, 両者が同じ機能を持つこ とを主張している (Bargh et al., 2001 ; Chartrand \& Bargh, 1996)。しかし，非意識的目標と意識的目標を直接比較 した研究は,これまで行われていなかった。また，従 来の研究では, ともすれば, 自動過程の結果は厄介な バイアスであり (“cognitive monster”, Bargh, 1999), 統制 過程の結果はその修正と位置づける傾向があった。一 方, 本研究では, 統制過程の弊害と自動過程の利点に 着目し，抑制のパラダイムを用いて，意識的抑制と， 非意識的な抑制の相違点を明らかにすることを試みた。

実験 1 では，非意識的に動機づけられた抑制におい ては，意識的に行われる抑制に伴う弊害である，抑制 の逆説的効果が生じないことが示された。続く，実験 2 では, 非意識的抑制は, 意識的抑制よりも制御資源 が消費されないだろうと予測された。主観的に抑制の 疲弊度を尋ねた項目では, 非意識的抑制群は疲弊を有 意に低く報告したが，後続のアナグラム課題では，意 識的抑制同様, 課題遂行数が減じており, 制御資源が 消費されている自我枯渴状態であると考えられた。

これら 2 つの実験から導かれる非意識的目標の特徵 は, 以下の通りである。まず, 非意識的抑制群におい て, 全ての参加者がプライミング操作およびその影響 に気がつかなかったことから，非意識的目標は，文字 通り意識を伴わないと言えるだろう。にもかかわらず, 外国人労働者を記述する課題において, 統制群よりも 有意にステレオタイプ的記述を避けており，すなわち， 意識的目標と同様の効果を持っていると考えられた

(実験 1.と2)。

重要なのは, 非意識的抑制群では, 意識的抑制群で 見られるような, 抑制の逆説的効果が生じなかった点 である(実験 1)。印象形成課題において, 意識的抑制群 では, ステレオタイプに基づく判断が統制群よりも高 かったのに対し, 非意識的抑制群では, そのような差 が見られなかった。このことから, 非意識な抑制では 「抑制しょう」といった明示的な意図は生じておらず， よって, 逆説的効果が生じなかったと解釈できるだろ う。加えて, 主観的な自己報告においては, 非意識的 抑制群は課題遂行における疲弊感も認識されていな かった（実験 1 と2)。

ところが, 抑制後の後続課題として, 実際に制御資 源を反映するアナグラム課題を行うと, 課題遂行が阻 害されており(実験 2), 非意識的目標であっても意識的
目標と同様に，制御資源が消費されていたと考えられ た。

このような結果が得られた理由としては，以下の 3 つの説明が可能であろう。

まず，非意識的に生じる目標においては，内的状態 の意識的報告が困難であったため, 行動指標との乘離 が生じた可能性が考えられる。先行研究においても, 参加者の内部で生じていることが自動的もしくは身体 的には探知できていても，その言語化や自己報告はで きないといった報告も多い (Nisbett \& Wilson, 1977)。実 際に，プライミング研究の多くでは，参加者はプライ ミング操作の影響に気がついていないばかりか，デブ リーフィングにおいて，選択や行動の理由を求められ ると，何らかの整合的な説明がその場で生成されるこ とがあるという(Bargh, 1997)。このような, 実際の内的 状態と内省報告の乘離により，意識的指標（=主観的に 尋权た困難感)では報告されない条件間の差が, 行動指標 (=アナグラム課題遂行数)では検出されたと考えられた。

このように考えると，実際には，非意識的目標も意 識的目標と同様に，制御資源を消費していたと推測さ れる。非意識的目標と意識的目標の違いは，文字通り， 当事者に意識されているか否かであるが，意識とは独 立して資源の消費は生じているのかもしれない。しか し，意識が伴わないだけで，実は自動過程もその実行 に資源を要しているとしたら，効率性を自動性の利点 として考える想定に再考を迫ることになり，他の研究 知見 (e.g., Chen \& Bargh, 1999) とは整合しないという, 興味深い問題が生じる。

最後に, 実際には, 非意識的目標は, 意識的目標ほ どは資源を消費していなかったが, 実験 2 の測定(アナ グラム課題）が，その差異を検出するに十分な敏感さを 備えていなかった可能性も残されている。制御資源の 残存量は, 個人差や状況の影響を受けやすく, アナグ ラム課題の成績や疲弊の報告では, 適切に捉えきれな いのかもしれない。今後は, これらの可能性を検討す るために, 行動・生理指標など, より精緻な制御資源 の指標を用いた追試が望まれる。非意識的目標と意識 的目標のそれぞれの特徵や相違点を明らかすることは, 目標研究, 自動性研究の両分野の実証的, 理論的, 応 用的発展において極めて重要な課題のひとつであり, 本研究の限界点も含めて, 今後も更なる検討が望まれ るだろう。

また, 本研究では, 抑制のリバウンド(実験 1) と制御 資源の測定(実験 2) は別々に行われた。これは, 両測定 を抑制後, 時間を置かずに行う必要があったためであ 
る。しかし, 今後は, 同じ実験内で検討していく必要 があるだろう。

本研究の結果は, また, 抑制研究においても有用な 示唆を与えると思われる。非意識的目標においては, 従来の研究で問題となっていた, 抑制の逆説的効果が 生じなかった。これまでの抑制の逆説的効果は, Wegner（1994）による皮肉過程理論で説明されること が多かった。これによると，抑制には，抑制を実行す る過程の他に, 監視過程が存在し, 何を抑制すべきか を常に参照しているという。しかしこの参照のために， かえつて抑制対象の活性化が上がってしまう逆説的効 果が生じるという。この逆説的効果は, 抑制意図が高 まるほど, 生じやすい(詳細は, 木村, 2003)。この理論に 基づいて, 逆説的効果の防止は, 極めて困難と考えら れている (e.g., Wenzlaff \& Wegner, 2000)。しかし, 本研 究は, このような逆説的効果低減に向けて, 自動的抑 制という一つの可能性を示したと言えるだろう。

同様に，望まないステレオタイプをどのように制御 するかは, 現在, 多くの研究者の関心を集めるところ である。ステレオタイプが活性化しても, 即座に平等 主義が活性化すれば，ステレオタイプ化が生じる前に 抑制が可能である (Moskowitz et al., 1999) のであれば, このようなプロセスを繰り返しによって自動化すれば, ステレオタイプの長期的な制御に䌘がるかもしれない

(同様の議論は, Monteith, Sherman, \& Devine, 1998)。

この非意識的目標の影響力は, 教育および臨床現場 へも少なからず示唆を与えるだろう。非意識的な過程 の影響力は現状では, ほとんど考慮されていない。し かし, 非意識的目標が課題への動機づけに関わると いった報告もあり（及川, 2005)，意識を明確に持つこと と同時に，いかにそれを自動化していくかということ も考えていく必要があるだろう。また，頑張るといっ た意志の行使が重圧となり，かえって失敗を招くこと があるように, 単に統制過程を強化するだけでは, 弊 害が生じる可能性もある。このような危険性を認識し， 注意を払っていく必要があるだろう。

我々は, 常に環境の影響を受け, 多くの行動を自覚 なしに生じさせている。今後は, 今までのように行動 の意図と行動, そしてそれに伴う意識を一つ一つ見て いくだけでなく,これらの相互の関連を明らかにして いく必要があるだろう。

\section{引用文献}

Bargh, J. A. 1990 Auto-motives : Preconscious determinants of social interaction. In E. T.
Higgins \& R. M. Sorrentino (Eds.), Handbook of motivation and cognition: vol.2. New York : Guilford Press. Pp.93-130.

Bargh, J. A. 1994 The four horsemen of automaticity : Awareness, intention, efficiency, and control in social cognition. In R. S. Wyer \& T. K. Srull (Eds.), Handbook of social cognition : vol.1 (2nd ed.). Hillsdale, $\mathrm{NJ}$ : Lawrence Erlbaum Associates. Pp.1-40.

Bargh, J. A. 1997 The automaticity of everyday life. In R. S. Wyer, Jr. (Ed.), The automaticity of everyday life: Advances in social cognition: vol. 10. Mahwah, NJ : Erlbaum. Pp.1-61.

Bargh, J. A. 1999 The cognitive monster : The case against the controllability of automatic stereotype effects. In S. Chaiken \& Y. Trope (Eds.), Dual-process theories in social psychology. New York : Guilford Press. Pp.361-382.

Bargh, J. A., \& Chartrand, T. L. 1999 The unbearable automaticity of being. American Psychologist, 54, 462-479.

Bargh, J. A., \& Chartrand, T. L. 2000 The mind in the middle : A practical guide to priming and automaticity research. In $\mathrm{H}$. Reis \& C. Judd (Eds.), Handbook of research methods in social and personality psychology. New York : Cambridge University Press. Pp.253-285.

Bargh, J. A., \& Gollwitzer, P. M. 1994 Environmental control of goal-directed action : Automatic and strategic contingencies between situations and behavior. In W. D. Spaulding (Ed.), Nebraska symposium on motivation: vol.41. Integrative views of motivation, cognition, and emotion. Lincoln, NE : University of Nebraska Press. Pp.71-124.

Bargh, J. A., Gollwitzer, P. M., Lee-Chai, A., Barndollar, K., \& Trötschel, R. 2001 Automated will : Nonconscious activation and pursuit of behavioral goals. Journal of Personality and Social Psychology, 81, 1014-1027.

Baumeister, R. F., Bratslavsky, E., Muraven, M., \& Tice, D. M. 1998 Ego depletion : Is the active self a limited resource? Journal of Personality and Social Psychology, 74, 1252-1265.

Baumeister, R. F., Muraven, M., \& Tice, D. M. 
2000 Ego depletion : A resource model of volition, self-regulation, and controlled processing. Social Cognition, 18, 130-150.

Chaiken, S., \& Trope, Y. (Eds.) 1999 Dual-process theories in social psychology. New York: Guilford Press.

Chartrand, T. L., \& Bargh, J. A. 1996 Automatic activation of impression formation and memorization goals : Nonconscious goal priming reproduces effects of explicit task instructions. Journal of Personality and Social Psychology, 71, 464-478.

Chen, M., \& Bargh, J. A. 1999 Nonconscious approach and avoidance : Behavioral consequences of the automatic evaluation effect. Personality and Social Psychology Bulletin, 25, 215-224.

Chen, S. \& Chaiken, S. 1999 The heuristic-systematic model in its broader context. In $\mathrm{S}$. Chaiken \& Y. Trope (Eds.), Dual-process theories in social psychology. New York: Guilford Press. Pp.73-96.

Clark, D. M., Ball, S., \& Pape, D. 1991 An experimental investigation of thought suppression. Behaviour Research and Therapy, 29, 253-257.

Davies, M. I., \& Clark, D. M. 1998 Thought suppression produces rebound effect with analogue post-traumatic intrusions. Behaviour Research and Therapy, 36, 571-582.

Deci, E. L., \& Ryan, R. M. 1985 Intrinsic motivation and self-determination in human behavior. New York : Plenum.

Devine, P. G. 1989 Stereotypes and prejudice : Their automatic and controlled components. Journal of Personality and Social Psychology, 56, 5-18.

Dweck, C. S., \& Leggett, E. L. 1988 A social cognitive approach to motivation and personality. Psychological Review, 95, 256-273.

Finkel, E. J., \& Campbell, W. K. 2001 Self-control and accommodation in close relationships : An interdependence analysis. Journal of Personality and Social Psychology, 81, 263-277.

Fiske, S. T. 1998 Stereotyping, prejudice and discrimination. In D. T. Gilbert, S. T. Fiske, \&
G. Lindzey (Eds.), The handbook of social psychology : vol.2 (4 $4^{\text {th }}$ ed.). New York : McGrawHill. Pp.357-411.

Föster, J., \& Liberman, N. 2001 The role of attribution of motivation in producing postsuppressional rebound. Journal of Personality and Social Psychology, 81, 377-390.

Gordijn, E. H., Hindriks, I., Koomen, W., Dijksterhuis, A., \& Van Knippenberg, A. 2004 Consequences of stereotype suppression and internal suppression motivation : A self-regulation approach. Personality and Social Psychology Bulletin, 30, 212-224.

Hamilton, D. L., Katz, L. B., \& Leirer, V. O. 1980 Organizational processes in impression formation. In R. Hastie, T. M. Ostrom, E. B. Ebbesen, R. S. Wyer, Jr., D. L. Hamilton, \& D. E. Carlston (Eds.), Person memory : The cognitive basis of social perception. Hillsdale, NJ : Erlbaum. Pp.121-153.

Higgins, E. T. 1987 Self-discrepancy : A theory relating self and affect. Psychological Review, 94, 319-340.

Higgins, E. T., \& Bargh, J. A. 1992 Unconscious sources of subjectivity and suffering : Is consciousness the solution? In L. L. Martin \& A. Tesser (Eds.), The construction of social judg. ments. Hillsdale, NJ : Erlbaum. Pp.67-103.

池上知子 2001 自動的処理 - 統制的処理一意識と無 意識の社会心理学一 唐沢 穣, 池上知子, 唐沢 かおり, 大平英樹(著) 社会的認知の心理学一社 会を描く心のはたらきー ナカニシヤ出版 Pp. $130-151$.

木村 晴 2003 思考抑制の影響とメンタルコント ロール方略 心理学評論, 46, 584-596. (Kimura, H. 2003 Effects of thought suppression and effective strategies of mental control. Japanese Psychological Review, 46, 584-596.)

木村 晴 2004 望まない思考の抑制と代替思考の効 果 教育心理学研究, 52, 115-126. (Kimura, H. 2004 The effects of suppressing unwanted thoughts and replacement strategy. Japanese Journal of Educational Psychology, 52, 115-126.)

Martin, L. L. 1986 Set/reset : Use and disuse of concepts in impression formation. Journal of 
Personality and Social Psychology, 18, 1-16.

Macrae, C. N., Bodenhausen, G. V., Milne, A. B., \& Jetten, J. 1994 Out of mind but back in sight : Stereotypes on the rebound. Journal of Personality and Social Psychology, 67, 808-817.

Mischel, W., Shoda, Y., \& Rodriguez, M. L. 1989 Delay of gratification in children. Science, 244, 933-938.

Monteith, M. J., Sherman, J. W., \& Devine, P. G. 1998 Suppression as a stereotype control strategy. Personality and Social Psychology Review, 2, 63-82.

森津太子・木村 晴 2004 自動性とコントロール過 程 大島 尚, 北村英哉(編著) ニューセンチュ リー社会心理学 3 認知の社会心理学 北樹出 版 Pp.43-53.

Moskowitz, G. B., Gollwitzer, P. M., Wasel, W., \& Schaal, B. 1999 Preconscious control of stereotype activation through chronic egalitarian goals. Journal of Personality and Social Psychology, 77, 167-184.

Moskowitz, G. B., Salomon, A. R., \& Taylor, C. M. 2000 Preconsciously controlling stereotyping : Implicitly activated egalitarian goals prevent the activation of stereotypes. Social Cognition, 18, 151-177.

麦谷周一 2004 ステレオタイプの抑制とリバウンド 同志社大学文学部 卒業論文 (未刊行)

Muraven, M., \& Baumeister, R. F. 2000 Selfregulation and depletion of limited resources: Does self-control resemble a muscle? Psychological Bulletin, 126, 247-259.

Muraven, M., Tice, D. M., \& Baumeister, R. F. 1998 Self-control as limited resource : Regulatory depletion patterns. Journal of Personality and Social Psychology, 74, 774-789.

Nisbett, R. E., \& Wilson, T. D. 1977 Telling more than we can know : Verbal reports on mental processes. Psychological Review, 84, 231-259.

Oikawa, M. 2004 Moderation of automatic achievement goals by conscious monitoring. Psychological Reports, 95, 975-980.

及川昌典 2005 知能観が非意識的な目標追求に及ほ す影響 教育心理学研究， 53，14-25. (Oikawa, M. 2005 Participants' theories of intelligence and pursuit of nonconscious goals. Japanese Journal of Educational Psychology, 53, 14-25.)

Schwarz, N., \& Bless, H. 1992 Constructing reality and its alternatives : An inclusion/exclusion model of assimilation and contrast effects in social judgment. In L. L. Martin \& A. Tesser (Eds.), The construction of social judgments. Hillsdale, NJ : Erlbaum. Pp.217-245.

Srull, T. K., \& Wyer, R. S., Jr. 1979 The role of category accessibility in the interpretation of information about persons : Some determinants and implications. Journal of Personality and Social Psychology, 37, 1660-1672.

Webster, D. M., Richter, L., \& Kruglanski, A.W. 1996 On leaping to conclusions when feeling tired : Mental fatigue effects on impressional primacy. Journal of Experimental Social Psy. chology, 32, 181-195.

Wegner, D. M. 1994 Ironic processes of mental control. Psychological Review, 101, 34-52.

Wegner, D. M., Schneider, D. J., Carter, S. R., \& White, T. L. 1987 Paradoxical effects of thought suppression. Journal of Personality and Social Psychology, 53, 5-13.

Wenzlaff, R. M., \& Wegner, D. M. 2000 Thought suppression. Annual Review of Psychology, 51, 59-91.

\section{謝辞}

論文作成にあたりご指導・ご助言いただきました一 橋大学の村田光二教授に心より感謝いたします。また, 抑制研究に関しまして貴重なご助言を下さった木村晴 先生（東京大学）に厚くお礼申し上げます。

(2004.9.9 受稿, '05.4.28 受理) 


\section{How Do Conscious and Unconscious Goals Differ? Suppression of Stereotypes by Instructions or Priming \\ MASANORI OIKAWA (GRAdUate SCHOOL OF SOCIOLOGY HITOTSUbashi UNIVERSITY) \\ JAPANESE JOURNAL OF EDUCATIONAL. PSYCHOLOGY, 2005, 53, 504-515}

Recent research on goal effects has indicated that conscious and unconscious goals share similar characteristics and functions. However, the extent to which these 2 forms of goal pursuits differ, and under what conditions, is unclear. In the present study, 2 experiments utilizing a suppression paradigm were conducted to demonstrate the difference between suppression that is induced consciously via instructions, and suppression induced unconsciously via egalitarian goal priming. Experiment 1 demonstrated that unconscious suppression did not lead to paradoxical effects, a by-product accompanying conscious suppression. Those participants who were instructed to avoid stereotyping foreigners during a writing task engaged in more stereotyping in a subsequent impression-formation task. This result was not found in the unconscious suppression group. In Experiment 2, based on the assumption that unconscious suppression is more efficient than conscious suppression, it was predicted that unconscious suppression would be less resource-consuming. A self-report measure after the suppression task indicated that only the participants in the conscious suppression condition reported increased fatigue. However, performance on a subsequent anagram task indicated that the performance of both groups was equally degraded, and no difference was observed between the 2 groups in the amount of ego-depletion.

Key Words : auto-motive, thought suppression, paradoxical effects, regulatory resources, stereotype 